Article

\title{
Effect of metal content on the activity and product selectivity of n-decane hydroisomerization over Ni-Pd/HY zeolite
}

\author{
Dhanapalan Karthikeyan a,c,*, Raji Atchudan b,\#, Raji Sivakumara \\ a Department of Chemistry, Arignar Anna College of Arts and Science, Krishnagiri-635001, Tamilnadu, India \\ b School of Chemical Engineering, Yeungnam University, Gyeongsan 38541, Republic of Korea \\ c Department of Chemistry, Anna University, Guindy Campus, Chennai-600025, India
}

\section{A R T I C L E I N F O}

\section{Article history:}

Received 18 May 2016

Accepted 9 July 2016

Published 5 November 2016

\section{Keywords:}

Hydroisomerization

$n$-Decane

Zeolite Y

Palladium

Impregnation method

\begin{abstract}
A B S T R A C T
Metal-loaded zeolite catalysts were synthesized and examined in the hydroisomerization of $n$-decane. Specifically, zeolite $\mathrm{Y}$ was impregnated with $0.1 \mathrm{wt} \% \mathrm{Pd}$ and varying amounts of $\mathrm{Ni}$ (0.1-0.5 wt\%). The crystallinity of the metal-loaded catalysts was characterized by X-ray diffraction, and the average metal particle size was determined by transmission electron microscopy. The states of Pd and Ni were identified by X-ray photoelectron spectroscopy. Ammonia temperature-programmed desorption analysis revealed the occurrence of ion-exchange of some of the catalyst acid sites with $\mathrm{Ni}^{2+}$. The reducibility of the $\mathrm{HY}$ zeolite-supported $\mathrm{Pd}, \mathrm{Ni}$, and Pd-Ni catalysts was studied by temperature-programmed reduction. The hydroisomerization of $n$-decane over the prepared catalyst was conducted at $200-450{ }^{\circ} \mathrm{C}$ under $1 \mathrm{~atm}$. Ni addition of up to $0.3 \mathrm{wt} \%$ over $0.1 \mathrm{wt} \%$ $\mathrm{Pd} / \mathrm{HY}$ enhanced the $n$-decane conversion and isomerization product selectivity. The improved selectivity of the mono- and dibranched isomers suggested the occurrence of a protonated cyclopropane intermediate mechanism. However, further Ni addition above $0.3 \mathrm{wt} \%$ considerably reduced the activity and isomerization selectivity. The bimetallic catalysts were more selective toward the formation of dibranched isomers, i.e., those containing a higher octane number.
\end{abstract}

(C) 2016, Dalian Institute of Chemical Physics, Chinese Academy of Sciences. Published by Elsevier B.V. All rights reserved.

\section{Introduction}

Bifunctional catalysts with metallic and acidic functionalities are commonly used in numerous industrial processes in petroleum refining and the petrochemical industry [1,2]. Transition metals can catalyze reactions such as isomerization, (de)hydrogenation, hydrogenolysis, aromatization, and cyclization of hydrocarbons [3]. However, their ability to chemisorb hydrogen, hydrocarbons, and other molecules varies with the chemical nature of the element [4]. Pt and Pd are the most important transition metals used in catalysis and can catalyze diverse hydrocarbon reactions [5-7]. $\gamma-\mathrm{Al}_{2} \mathrm{O}_{3}$ is a typical acid component present in commercially used reforming catalysts. However, zeolites are gaining increasing attention for application in processes such as hydroisomerization, hydrocracking, and dewaxing [8-11]. In the presence of bifunctional catalysts, dehydrogenation (hydrogenation) of hydrocarbons occurs on the metal sites, whereas isomerization and $\mathrm{C}-\mathrm{C}$ bond cleavage occur on the Brönsted acid sites [12-14]. Hence, the balance between the metallic and acidic sites is important because it determines the activity of the reaction, stability of the catalyst, and selectivity of the product. Considerable efforts have been invested in understanding the reaction mechanism, which leads to the formation of isomers as well as cracked products from

\footnotetext{
* Corresponding author. E-mail: dkarthikeyan05@yahoo.co.in

\# Corresponding author. E-mail: atchudanr@yu.ac.kr

DOI: 10.1016/S1872-2067(16)62507-X | http://www.sciencedirect.com/science/journal/18722067 | Chin. J. Catal., Vol. 37, No. 11, November 2016
} 
normal and branched paraffins over bifunctional zeolites [15-17]. According to the classical isomerization mechanism $[13,18]$, paraffins are dehydrogenated on the catalyst metal sites, and the formed olefins are protonated on the acid sites to the corresponding alkylcarbenium ions. These carbenium ions undergo skeletal rearrangement and $\beta$-scission followed by deprotonation and hydrogenation to the corresponding paraffins over the metal sites. The selectivity of paraffin isomerization (defined as the ratio of the isomerized to the cracking products) depends primarily on the balance between the metal and acid catalyst functions that control the rate of the isomerization and $\beta$-scission reactions.

Arifulin et al. [19] studied the effect of organic compound impurities on the hydroisomerization of decane over a Pd-based catalyst. The results showed that the presence of 1-octene, decalin, ethylbenzene, or naphthalene ( $2 \mathrm{~mol} / \mathrm{L}) \mathrm{had}$ negligible effects on the activity of an aluminopalladium sulfide catalyst in the hydroisomerization of decane at $40 \mathrm{~atm}$ and 400 ${ }^{\circ} \mathrm{C}$. However, the isomerization of decane decreased by $20 \%-25 \%$ in the presence of $10 \mathrm{~mol} \%$ ethylbenzene and naphthalene mixtures. The presence of acenaphthene, benzothiophene, or aniline ( $2 \mathrm{~mol} \%$ ) prevented the reaction from proceeding. Martens et al. [20-22] examined the isomerization of decane over $0.5 \%-1 \%$ Pt supported on ferrierite, BETA, and Y zeolites. The product distribution obtained over the ferrierite catalysts differed from that over the two remaining catalysts. This result suggested that the BETA and Y zeolite catalysts featured the same void volume structure. Small variations in the physicochemical properties of a given zeolite structure do not significantly influence the product distribution. The product distribution pattern is the only accurate information on the pore size and structure. Alvarez et al. [23] demonstrated a quantitative relationship between activity, stability, and product selectivity in the hydroisomerization and hydrocracking of n-decane over bifunctional Pt/HY catalysts and the ratio of the number of metallic sites to the number of acid sites. In the presence of abundant acid sites, direct $n$-decane isomerization and cracking into the corresponding products occurred. When the number of acid sites was below $6, n$-decane transformed successively into monobranched isomers, dibranched isomers, and cracking products. In the latter case, the catalysts can be considered as ideal bifunctional catalysts as there are no reaction limitations by the hydrogenation and dehydrogenation steps or the migration of olefinic intermediates between hydrogenating sites. Therefore, the activity per acid site is maximal, and the apparent reaction scheme matches the transformation scheme of olefinic intermediates. Zakumbaeva et al. [24] investigated the effect of decationized forms of zeolites (HZSM, HY, and clinoptilolite) and reaction temperature on the hydrocracking and hydroisomerization activity of zeolite-containing catalysts modified by metals in the conversion of $n$-decane. GK-3 catalyst based on high-silica HZSM-zeolite displayed the highest hydrocracking, hydroisomerization, and hydrodesulfurization activity and selectivity. Elangovan et al. [25] examined the hydroconversion of $n$-decane over bifunctional catalysts comprising bimetallic Pt-Pd clusters supported on an AlMCM-41 ( $\mathrm{Si} / \mathrm{Al}=23)$ mesoporous molecular sieve. The catalytic activity of the bimetallic Pt-Pd catalysts was higher than that of the monometallic Pt and Pd catalysts. Additionally, the good balance between the two catalytic functions, namely acid sites and metal sites, afforded a higher isomer yield at a substantially lower reaction temperature. Moreover, cracking on the metal sites (hydrogenolysis) was largely suppressed over certain bimetallic catalysts. Rezgui et al. [26] reported the hydroconversion of $n$-decane over $\mathrm{Ni}-\mathrm{W} / \mathrm{SiO}_{2}-\mathrm{Al}_{2} \mathrm{O}_{3}$ with different $\mathrm{Ni}$ and $\mathrm{W}$ concentrations $(12 \%-17 \% \mathrm{Ni}$ and $8 \%-30 \%$ W). $n$-Decane isomerization and cracking to the corresponding products were dependent on both the metal content (up to $15 \%$ of $\mathrm{Ni}$ ) and acid sites. The extent of isomerization increased subsequently owing to imbalance in the metal-to-acid sites content. The combination of $15 \% \mathrm{Ni}$ and $10 \% \mathrm{~W}$ provided optimum balance between the acid and metal functions, realizing $42.3 \%$ of $n$-decane conversion and $55 \%$ of isomerization product selectivity at $100 \mathrm{~min}$ of reaction.

To date, few reports are available in the literature that examine the addition of $\mathrm{Ni}$ as the second metal to $\mathrm{Pd}$; moreover, high $\mathrm{Ni}$ loadings ( $\geq 1.0 \mathrm{wt} \%$ ) have been typically studied. In the present study, nickel was introduced as the second metal at low concentrations $(<1.0 \mathrm{wt} \%)$ to modify the catalytic properties of Pd-supported zeolite Y toward $n$-decane hydroisomerization. Additionally, variations in the product distribution were examined in terms of metal loading, and reaction temperature and activity.

\section{Experimental}

\subsection{Catalyst preparation}

The sodium form of zeolite $\mathrm{Y}\left(\mathrm{SiO}_{2} / \mathrm{Al}_{2} \mathrm{O}_{3}=6\right)$ was supplied by United Catalyst India Ltd., India. HY was obtained by repeated ion-exchange of zeolite $\mathrm{Y}$ with aqueous $1 \mathrm{~mol} / \mathrm{L} \mathrm{NH}_{4} \mathrm{Cl}$ solution followed by calcination at $550{ }^{\circ} \mathrm{C}$ for $5 \mathrm{~h}$. HY was then loaded with $0.1 \mathrm{wt} \% \mathrm{Pd}$ by incipient wetness impregnation (IWI), and the resulting material is referred to as catalyst $B_{1}$. Then, $\mathrm{B}_{1}$ was impregnated by IWI with $0.1,0.2,0.3,0.4$, and 0.5 wt $\% \mathrm{Ni}$, and the resulting samples are designated as $\mathrm{B}_{2}, \mathrm{~B}_{3}, \mathrm{~B}_{4}$, $\mathrm{B}_{5}$, and $\mathrm{B}_{6}$, respectively. For comparison purposes, $0.3 \mathrm{wt} \% \mathrm{Ni}$ was prepared by the IWI method, and the resulting material is designated as catalyst B7. Aqueous solutions of palladium chloride (Sisco Research Laboratory, India) and nickel nitrate (Central Drug House, India) were used as sources of Pd and $\mathrm{Ni}$, respectively. The metal-loaded catalysts were dried at $120{ }^{\circ} \mathrm{C}$ for $24 \mathrm{~h}$. Then, the catalysts $(1 \mathrm{~g})$ were packed in a quartz reactor and activated at $550{ }^{\circ} \mathrm{C}$ for $3 \mathrm{~h}$ under $\mathrm{N}_{2}$ atmosphere. The temperature was then lowered to $475^{\circ} \mathrm{C}$ under hydrogen flow (30 $\mathrm{mL} \mathrm{min}^{-1} \mathrm{~g}^{-1}$ ) for $6 \mathrm{~h}$ to reduce the metal ions.

\subsection{Characterization}

\subsubsection{X-ray diffraction (XRD) measurements}

The purity of the HY and metal-loaded zeolites was analyzed by XRD on an X'Pert X-ray diffractometer, operating with Ni-filtered $\mathrm{Cu} K_{\alpha}$ radiation $(\lambda=1.54 \AA)$ in the scan range of $2 \theta=$ $5^{\circ}-50^{\circ}$. 


\subsubsection{Surface area measurements}

The specific surface area of the catalysts was determined by nitrogen sorption using the Brunauer-Emmett-Teller method; the nitrogen sorption data were acquired on a Quantachrome Autosorb automated gas sorption instrument. Prior to the measurements, all samples were degassed at $400{ }^{\circ} \mathrm{C}$ for $6-8 \mathrm{~h}$ under a flow of $\mathrm{N}_{2}$ at $60 \mathrm{~mL} / \mathrm{min}$.

\subsubsection{Temperature-programmed desorption of ammonia ( $\left.\mathrm{NH}_{3}-\mathrm{TPD}\right)$ analysis}

The concentration of acid sites of the catalysts was measured by $\mathrm{NH}_{3}$-TPD on a Micromeritics TPD/TPR 2900 analyzer. The catalysts $(150 \mathrm{mg}$ ) were housed in a quartz tubular reactor and pretreated in flowing helium ( $\geq 99.999 \%$ purity) while heating to $550{ }^{\circ} \mathrm{C}$ at $10{ }^{\circ} \mathrm{C} / \mathrm{min}$. After maintaining the temperature for $30 \mathrm{~min}$, the catalysts were cooled to $210{ }^{\circ} \mathrm{C}$ and saturated for $15 \mathrm{~min}$ in an ammonia stream ( $\geq 99.999 \%$ purity). The catalysts were then allowed to equilibrate in a flow at $210{ }^{\circ} \mathrm{C}$ for $1 \mathrm{~h}$. Then, ammonia was desorbed by heating the catalysts at $800{ }^{\circ} \mathrm{C}$ at a linear heating rate of $15^{\circ} \mathrm{C} / \mathrm{min}$. The temperature and detector signals were recorded simultaneously. The area under the obtained curve was integrated to determine the relative total acidity of the catalysts. Weak and strong acidities, as measured by the concentration of weak and strong acid sites, respectively, were determined by integration of the area under the peaks at the lowest and the highest temperatures, respectively $[27,28]$.

\subsubsection{Temperature-programmed reduction (TPR) measurements}

TPR measurements were performed using the same apparatus as that used for the TPDA analysis. After metal loading, the sample (150 mg) was degassed by heating to $550{ }^{\circ} \mathrm{C}$ at 30 ${ }^{\circ} \mathrm{C} / \mathrm{min}$ in an argon flow, after which the temperature was maintained for $30 \mathrm{~min}$. Then, the sample was cooled to room temperature and stabilized under an argon/hydrogen flow ( $\geq 99.999 \%$ purity, 85:15 v/v). The temperature and detector signals were then continuously recorded while heating to 550 ${ }^{\circ} \mathrm{C}$ at $20^{\circ} \mathrm{C} / \mathrm{min}$. The liquids formed during the reduction process were collected by a cooling trap positioned between the sample and detector.

\subsubsection{X-ray photoelectron spectroscopy (XPS) analysis}

The oxidation state of palladium and nickel in catalysts $\mathrm{B}_{4}$ and $\mathrm{B}_{6}$ was reduced at $475{ }^{\circ} \mathrm{C}$ for $6-7 \mathrm{~h}$ and analyzed by XPS. The XPS spectra were acquired on a surface analysis system (KRATOS ESCA model AXIS 165) using Mg $K_{\alpha}$ radiation (1253.6 $\mathrm{eV}$ ) and a pass energy of $50 \mathrm{eV}$. During spectral acquisition, the pressure of the analysis chamber was maintained at $<1 \times 10^{-7}$ torr.

\subsubsection{Transmission electron microscopy (TEM) analysis}

TEM analysis of the reduced catalysts was conducted on a JEM-2000 FX-II-JEOL electron microscope, operating at $300 \mathrm{kV}$. Specimens were enlarged using a thin photographic paper. The size of all the metal particles visible in each photograph was measured manually and averaged.

\subsection{Catalytic studies}

The catalytic reactions were performed in a fixed-bed continuous down-flow quartz reactor under $1 \mathrm{~atm}$. About $1 \mathrm{~g}$ of the metal-loaded catalysts was packed in the reactor, which was then introduced into a tubular furnace. The reactor system was flushed with dry nitrogen for $3 \mathrm{~h}$, and then the metals were reduced at $475{ }^{\circ} \mathrm{C}$ under hydrogen flow $\left(30 \mathrm{~mL} \mathrm{~min}^{-1} \mathrm{~g}^{-1}\right.$ ) for 3-6 h. After the reduction process, the temperature was lowered to the reaction temperature. The reactant $n$-decane was fed into the reactor by a syringe pump at a liquid hour space velocity (LHSV) of $2 \mathrm{~h}^{-1}$, and pure hydrogen gas at a flow rate of $20 \mathrm{~mL} \mathrm{~min}^{-1} \mathrm{~g}^{-1}$ was flowed. The reaction gas mixture was heated in the temperature range of $200-450{ }^{\circ} \mathrm{C}$. The obtained products flowed through a condenser, which was attached to the end of the reactor, under ice-cold conditions and were collected in a trap kept in ice at time intervals of $1 \mathrm{~h}$. The products were then analyzed on an AIMIL NUCON 5765 gas chromatograph equipped with a PIONA column and a flame ionization detector and identified by gas chromatography-mass spectrometry (PerkinElmer QP5000).

\section{Results and discussion}

\subsection{Characterization}

\subsubsection{XRD}

The XRD pattern (not shown) of zeolite $Y$ featured intense diffraction peaks within a $2 \theta$ range of $2^{\circ}-50^{\circ}$, which are in good agreement with those displayed by the standard reference [29]. The XRD patterns of the metal-loaded zeolite catalysts are shown in Fig. 1. As observed, the intensity of the XRD peaks decreased with increasing $\mathrm{Ni}$ added amounts. Specifically, the intensity of the XRD peaks of $\mathrm{B}_{2}-\mathrm{B}_{7}$ at $2 \theta=6.13^{\circ}, 15.49^{\circ}, 23.51^{\circ}$, $24.39^{\circ}, 26.83^{\circ}, 31.13^{\circ}$, and $43.05^{\circ}$ decreased with increasing $\mathrm{Ni}$ added amounts likely because of pore blockage by the Ni species. Intense peaks of $\mathrm{Pd}(111,200), \mathrm{Ni}$ (cubic), and NiO (hexagonal) are known to appear at $2 \theta$ values of $40^{\circ}, 46.5^{\circ}, 44.5^{\circ}$, and $43.3^{\circ}$, respectively, as reported by Faherazzi et al. [30] and

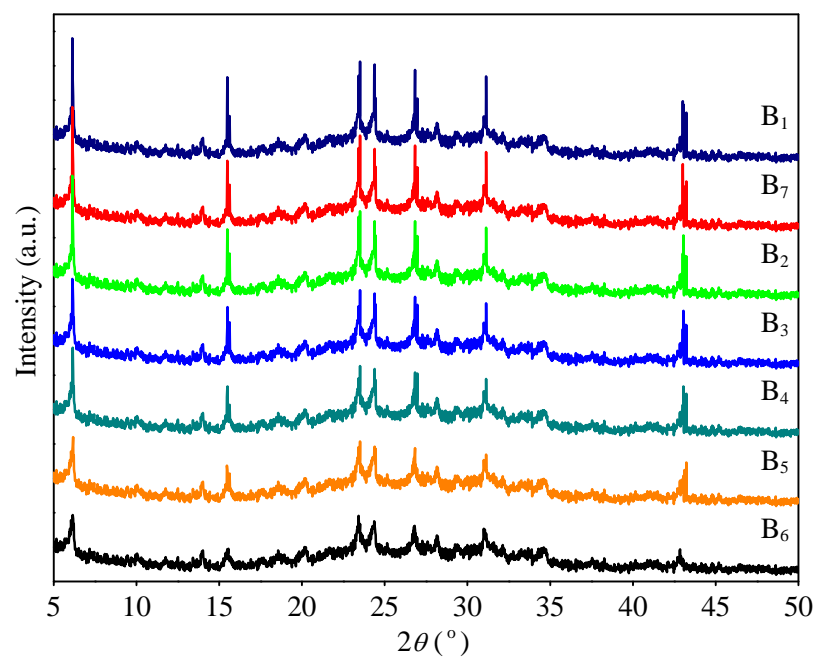

Fig. 1. XRD patterns of $B$ series catalysts. 


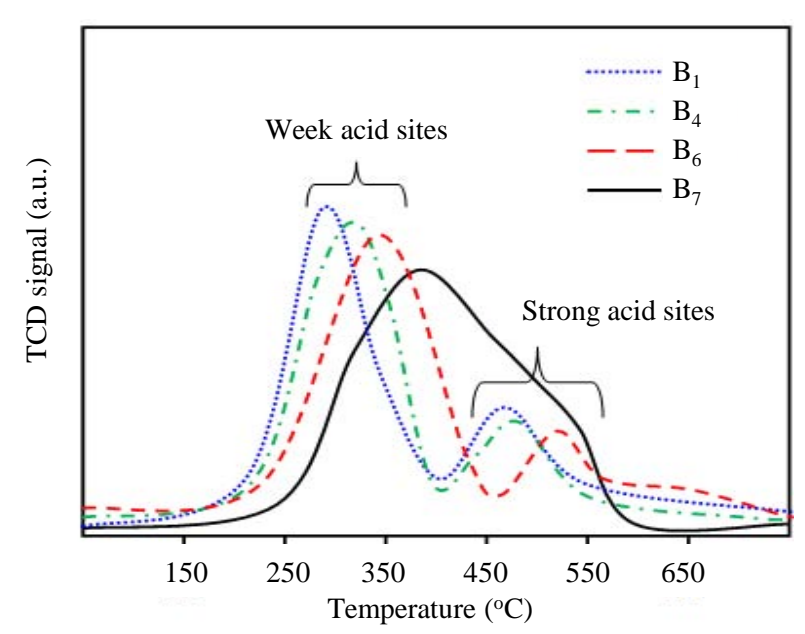

Fig. 2. $\mathrm{NH}_{3}$-TPD curves for $\mathrm{B}_{1}, \mathrm{~B}_{4}, \mathrm{~B}_{6}$ and $\mathrm{B}_{7}$ catalysts.

Cullity et al. [31]. However, these peaks were not detected in the present study, suggesting that the size of the metal particles is below the detection limit of the XRD technique.

\subsection{2. $\mathrm{NH}_{3}-\mathrm{TPD}$}

The $\mathrm{NH}_{3}$-TPD profiles, characterizing adsorbed $\mathrm{NH}_{3}$ on the different catalysts, are shown in Fig. 2. The position of the peaks varied considerably depending on the metal loading. However, in all cases, two peaks were observed at $~ 343$ and $518^{\circ} \mathrm{C}$. These two peaks could be attributed to the desorption of ammonia from weak and strong acid sites, respectively. The amount of desorbed ammonia and the desorption temperature were considered as a measure of the total acidity and acid strength of the catalysts, respectively [32]. As observed from Table 1, the amount of ammonia adsorbed at the lower temperature (indicative of weak acidity) was always greater than that adsorbed at the higher temperature (indicative of strong acidity). Furthermore, a higher Ni loading decreased the total acidity of the bimetallic catalysts. The decrease in acidity of the bimetallic catalysts with higher nickel loadings could be attributed to the occupation of some acid sites by the added nickel species [33-36]. In addition, this result could also be related to Ni combining with the Pd particles and the likely growth of the Ni-Pd particles. The same results have been reported in our previous work [36]. Furthermore, as observed in Table 1, the surface area of the catalysts decreased slightly with increasing

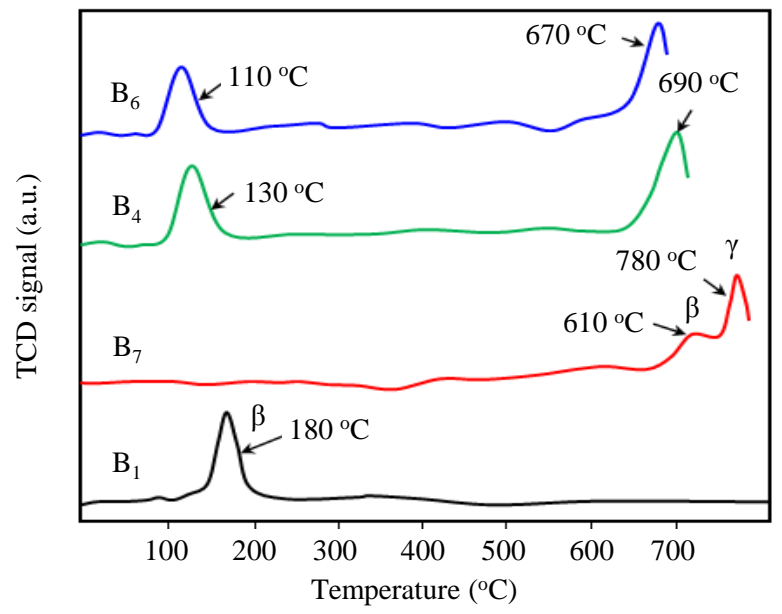

Fig. 3. TPR curves for $\mathrm{B}_{1}, \mathrm{~B}_{4}, \mathrm{~B}_{6}$ and $\mathrm{B}_{7}$ catalysts.

Ni loading. This result suggested partial blocking of the zeolite channels by the nickel species [37]. Moreover, a study [38] reported a decrease in acid site density and surface area when $\mathrm{Ni}$ was introduced in mordenite zeolite, which was also attributed to partial pore blockage by the Ni particles. As mentioned earlier, the peak temperature, corresponding to the ammonium desorption profile, was marginally influenced by an increase in $\mathrm{Ni}$ loading, indicating that the $\mathrm{Ni}$ content only slightly affected the strength of the acid sites (Fig. 2) [35].

\subsubsection{TPR}

TPR studies were conducted to determine the relative differences in the reducibility of the catalysts impregnated with different metal loadings. The TPR results of the monometallic catalysts (Pd/HY or Ni/HY) and bimetallic catalysts (Pd-Ni/HY) are presented in Table 1 and Fig. 3. The TPR profile of $\mathrm{B}_{7}$ featured two reduction peaks at 610 and $780{ }^{\circ} \mathrm{C}$, corresponding to $\beta$ - and $\gamma$-peaks, according to Suzuki and co-workers [39]. The distribution of nickel ions in zeolite $\mathrm{Y}$ was discussed by these authors using the TPR technique, and they found that the reducibility of the $\mathrm{Ni}^{2+}$ ions occupying sites $\mathrm{S}_{\mathrm{I}}\left(\alpha\right.$ cavity), $\mathrm{S}_{\mathrm{I}}^{\prime}$ (sodalite cavity) and $\mathrm{S}_{\mathrm{II}}$ or $\mathrm{S}_{\mathrm{II}}{ }^{\prime}$ (hexagonal prisms) increased in that order. Thus, according to the reported observations, the hydrogen consumption peaks of $\mathrm{B}_{7}$ could be attributed to the reduction of $\mathrm{Ni}^{2+}$ cations located in sites belonging to sodalite cages ( $\beta$-peak) and hexagonal prisms ( $\gamma$-peak), respectively.

Table 1

Physicochemical characteristics of B series catalysts.

\begin{tabular}{|c|c|c|c|c|c|c|c|c|c|}
\hline \multirow{2}{*}{ Catalyst } & \multirow{2}{*}{$\begin{array}{l}\text { Pd content } \\
(w t \%)\end{array}$} & \multirow{2}{*}{$\begin{array}{l}\text { Ni content } \\
\text { (wt } \%)\end{array}$} & \multirow{2}{*}{$\begin{array}{c}\text { Surface } \\
\text { area }\left(\mathrm{m}^{2} / \mathrm{g}\right)\end{array}$} & \multirow{2}{*}{$\begin{array}{l}\text { Porevolume } \\
\left(\mathrm{cm}^{3} / \mathrm{g}\right)\end{array}$} & \multicolumn{3}{|c|}{$\mathrm{NH}_{3}-\mathrm{TPD}^{\text {a }}\left(\mathrm{mmol} / \mathrm{g}_{\mathrm{cat}}\right)$} & \multirow{2}{*}{$\begin{array}{c}\text { Particle } \\
\text { size }(\mathrm{nm})\end{array}$} & \multirow{2}{*}{$\begin{array}{c}\text { Reduction } \\
\text { temperature }\left({ }^{\circ} \mathrm{C}\right)\end{array}$} \\
\hline & & & & & Weak acidity & Strong acidity & Total acidity & & \\
\hline HY & - & - & 367 & 0.632 & $0.447(276)$ & $0.168(452)$ & 0.615 & - & - \\
\hline $\mathrm{B}_{1}$ & 0.1 & - & 357 & 0.625 & $0.421(288)$ & $0.142(468)$ & 0.563 & - & 180 \\
\hline $\mathrm{B}_{2}$ & 0.1 & 0.1 & 332 & 0.603 & 0.407 (297) & $0.128(477)$ & 0.535 & - & - \\
\hline $\mathrm{B}_{3}$ & 0.1 & 0.2 & 312 & 0.591 & $0.384(312)$ & $0.114(489)$ & 0.498 & - & - \\
\hline $\mathrm{B}_{4}$ & 0.1 & 0.3 & 296 & 0.588 & $0.368(324)$ & $0.102(496)$ & 0.470 & 6.08 & 130,690 \\
\hline $\mathrm{B}_{5}$ & 0.1 & 0.4 & 274 & 0.561 & $0.342(331)$ & $0.094(508)$ & 0.436 & - & - \\
\hline $\mathrm{B}_{6}$ & 0.1 & 0.5 & 252 & 0.553 & $0.328(343)$ & $0.086(518)$ & 0.414 & 9.07 & 110,670 \\
\hline $\mathrm{B}_{7}$ & - & 0.3 & 324 & 0.598 & $0.312(328)$ & $0.132(496)$ & 0.444 & - & 610,780 \\
\hline
\end{tabular}

a The data in parentheses refer to the desorption temperature $\left({ }^{\circ} \mathrm{C}\right)$. 
In the TRP profiles of catalysts $\mathrm{B}_{4}$ and $\mathrm{B}_{6}$, the above two peaks shifted to much lower temperatures, and the area under the highest temperature Pd peak decreased with increasing $\mathrm{Ni}$ contents. Similar results were obtained by Feeley et al. [40] who examined Pd-Ni supported on HY zeolite. The peak shift was attributed to two effects: (1) an enhanced degree of reduction of the nickel species upon interaction with reduced Pd particles present in the supercages, which can dissociatively chemisorb hydrogen, and (2) a Pd-Ni ion-pair formation or nickel ions migration from hexagonal prisms to sodalite cages containing reduced $\mathrm{Pd}$ atoms.

Feeley et al. [40] also studied $\mathrm{Pd} / \mathrm{NaY}$ catalysts calcined at 250 and $550^{\circ} \mathrm{C}$; the catalysts displayed TPR reduction peaks at 150 and $200^{\circ} \mathrm{C}$, respectively. The authors concluded that in the first case, the $\mathrm{Pd}^{2+}$ ions were mostly present in the $\alpha$-cages where they could easily be reduced. For the $\mathrm{Pd} / \mathrm{NaY}$ sample calcined at the higher temperature, $\sim 70 \%$ of the $\mathrm{Pd}^{2+}$ ions migrated to the sodalite cages where reduction was more difficult. In the present work, the $0.1 \mathrm{wt} \% \mathrm{Pd} / \mathrm{HY}$ catalyst $\left(\mathrm{B}_{1}\right)$, which was calcined at $550{ }^{\circ} \mathrm{C}$, featured only one peak at $180^{\circ} \mathrm{C}$. Thus, the peak could be attributed to the reduction of $\mathrm{Pd}^{2+}$ located in the sodalite cages. The temperature difference of $20{ }^{\circ} \mathrm{C}$ between the lower peak temperature, corresponding to the reduction of $\mathrm{Pd}^{2+}$ ions located in $\beta$-positions of $\mathrm{HY}$, and the temperature observed by Feeley et al. [40] for HNaY could likely be related to the redox equilibrium, which was also observed in the reduction of Ni ions in acidic zeolites [41].

\subsubsection{XPS}

The XPS spectra of the Pd and Ni species in reduced catalysts $\mathrm{B}_{4}$ and $\mathrm{B}_{6}$ are shown in Fig. 4. The Pd XPS pattern featured two major peaks regardless of the support and amount of nickel. The peaks with binding energies of 336.4 and $342.0 \mathrm{eV}$ were attributed to the core level $\mathrm{Pd} 3 d_{5 / 2}$ and $\mathrm{Pd} 3 d_{3 / 2}$ transitions, respectively, indicating the presence of palladium in the metallic state. However, the presence of Pd in higher oxidation states could not be ruled out because of possible peak overlap with that of Al $2 p$ transition of the support [42]. The Ni $2 p_{3 / 2}$ XPS peaks were observed at 852.3 and $854.0 \mathrm{eV}$, indicating the presence of metallic nickel and $\mathrm{NiO}$, respectively. $\mathrm{B}_{6}$ featured a broad peak at $\sim 857.0 \mathrm{eV}$, indicating the presence of $\mathrm{Ni}^{2+}$ and

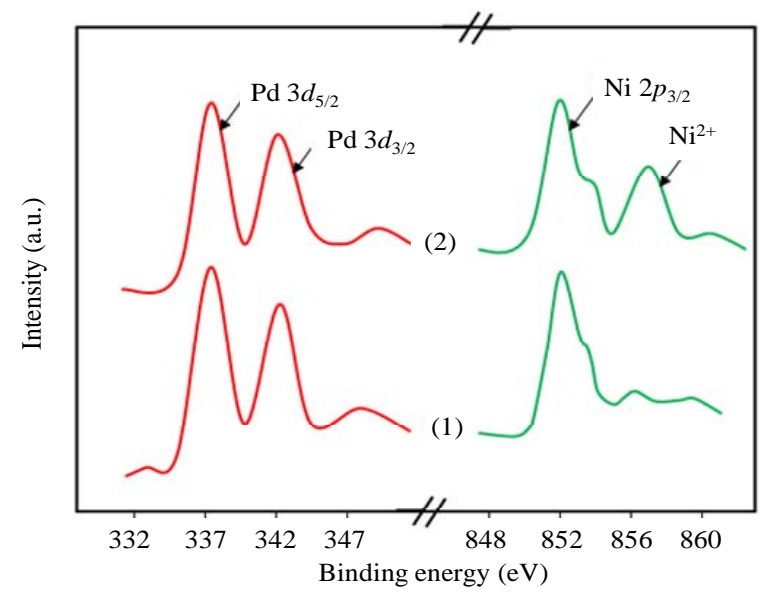

Fig. 4. XPS spectra of $B_{4}(1)$ and $B_{6}(2)$ catalysts. the formation of $\mathrm{NiAl}_{2} \mathrm{O}_{4}$, from which reduction of $\mathrm{Ni}^{2+}$ is very difficult (Ni metal: $852.3 \mathrm{eV}$; NiO: $853.3 \mathrm{eV} ; \mathrm{NiAl}_{2} \mathrm{O}_{4}$ : $857.2 \mathrm{eV}$ in Phi ESCA data book). In an XPS study on the reduction of NiY zeolites by Minchev et al. [43], the latter observed that nickel remained unreduced in the final product. Likewise, an XPS study on Ni-mordenite by Narayanan [44] revealed that the reduction of $\mathrm{Ni}$ in mordenite was rather difficult and during reduction, multiple species of nickel formed. Xiao et al. [45] examined the reduction and oxidation behavior of Ni-containing HZSM- 5 by XPS and observed the formation of nickel on the surface of the zeolite owing to the interaction between $\mathrm{Ni}^{2+}$ and zeolite. Furthermore, the authors observed a surface enrichment in aluminum and nickel. A TRP comparison study between $\mathrm{Ni} / \mathrm{NaY}$-zeolite and $\mathrm{Ni}$-Pd/NaY-zeolite by Feely et al. [40] revealed an enhanced reduction of $\mathrm{Ni}^{2+}$ to $\mathrm{Ni}^{0}$ by addition of $\mathrm{Pd}$. Likewise, in the present case, the added Pd is likely to favor the reduction of nickel cations within $\mathrm{Ni}$ added amounts of $0-0.3$ wt $\% \mathrm{Ni}$. Above this range, $\mathrm{NiO}$ was observed (e.g., $0.5 \mathrm{wt} \% \mathrm{Ni}$ ).

\subsubsection{TEM analysis}

TEM images of catalysts $\mathrm{B}_{4}$ and $\mathrm{B}_{6}$ are shown in Fig. 5. The black dots observed in the support matrix were attributed to the bimetallic (Ni-Pd) particles on the surface of the support. The average size of the particles on each support was determined and is given in Table 1. As observed in Table 1, the average particle size increased with increasing Ni added amounts. In the TPR spectra recorded by Feely et al. [40], the $\mathrm{Ni}(8.8)-\mathrm{Pd}(3.2) / \mathrm{NaY}$ catalysts displayed a decrease in the $\mathrm{Ni}$ reduction temperature with increasing Pd concentrations; the authors attributed this trend to the occurrence of collision among mobile palladium oxide particles by thermal migration and the presence of nickel oxide particles catalytically reduced by pre-reduced Pd particles. The average particle sizes of catalysts $\mathrm{B}_{4}$ and $\mathrm{B}_{6}$ were 6.08 and $9.07 \mathrm{~nm}$, respectively. The particles are larger than the pores of the zeolite support (pore size is 7.4 ̊̊: 12MR) and hence may be located mainly outside the pores as reported by Romero et al. [46] for Ni/HZSM-5 catalysts. Furthermore, the authors examined the effect of the $\mathrm{Ni}$ loading technique (ion-exchange and impregnation) employed on the particle size of Ni/HZSM- 5 by TEM. Large particles always formed on the external surfaces of the zeolite crystals regardless of the metal loading technique employed. Hence, the $\mathrm{Ni}-\mathrm{Pd}$ particles are likely to grow during reduction as a result of migration of Ni toward originally formed Ni-Pd particles.

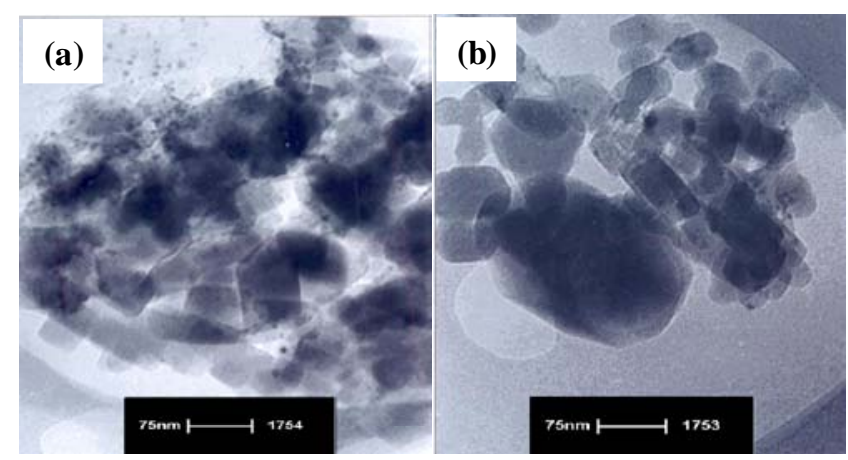

Fig. 5. TEM picture of catalysts $\mathrm{B}_{4}(\mathrm{a})$ and $\mathrm{B}_{6}(\mathrm{~b})$. 


\subsection{Catalytic studies}

Hydroisomerization of $n$-decane was examined over the reduced bifunctional catalysts at a LHSV of $2 \mathrm{~h}^{-1}$ and $200-450{ }^{\circ} \mathrm{C}$ in increments of $50{ }^{\circ} \mathrm{C}$. The monobranched isomers, 2-methylnonane (2-MC9), 3-methylnonane (3-MC9), 4-methylnonane (4-MC9), 5-methylnonane (5-MC9), and 3-ethyloctane (3-E8), and dibranched isomers, 2,3-dimethyloctane (2,3-DMC8), 2,4dimethyloctane (2,4-DMC8), 2,5-dimethyloctane (2,5-DMC8), and 2,6-dimethyloctane (2,6-DMC8), were the major products obtained owing to skeletal rearrangement of the carbon chain; the results are presented in Table 2 . Traces of cracked, aromatized, naphthenes and cyclized products were also observed. Products with more than 10 carbons were not observed. Likewise, the lowest carbon numbers $\left(\mathrm{C}_{1}-\mathrm{C}_{4}\right)$ were not detected under a wide range of operating conditions, thus ruling out the occurrence of hydrogenolysis reaction of the feed over the metal sites.

\subsubsection{Effect of reaction temperature on $n$-decane conversion and isomerization product selectivity}

The effect of temperature on $n$-decane conversion over all the catalytic systems prepared is illustrated in Fig. 6 . The extent of $n$-decane conversion initially increased with increasing reaction temperatures to up to $400{ }^{\circ} \mathrm{C}$ and thereafter decreased. Maximum conversion of $n$-decane over all the catalytic systems was observed at $400{ }^{\circ} \mathrm{C}$. In contrast, the isomerization selectivity of $n$-decane over all the catalytic systems increased to up to $350{ }^{\circ} \mathrm{C}$ and then decreased (Fig. 7). When the reaction temperature increased from 350 to $450{ }^{\circ} \mathrm{C}$, more undesirable cracked products were obtained. This result indicates that as tempera-

Table 2

Product distribution of $n$-decane hydroisomerization over B series of catalysts at $350^{\circ} \mathrm{C}$.

\begin{tabular}{lrrrrrrr}
\hline $\begin{array}{l}\text { Product distribution } \\
\text { (wt\%) }\end{array}$ & $\mathrm{B}_{1}$ & $\mathrm{~B}_{2}$ & $\mathrm{~B}_{3}$ & $\mathrm{~B}_{4}$ & $\mathrm{~B}_{5}$ & $\mathrm{~B}_{6}$ & $\mathrm{~B}_{7}$ \\
\hline 2-MC9 & 4.8 & 5.8 & 6.8 & 7.4 & 6.8 & 5.4 & 4.1 \\
3-MC9 & 8.2 & 9.7 & 11.5 & 12.4 & 11.5 & 9.2 & 7.9 \\
4-MC9 & 4.4 & 4.8 & 5.7 & 6.8 & 5.9 & 4.6 & 2.3 \\
5-MC9 & 1.7 & 2.2 & 3.0 & 3.9 & 3.2 & 2.2 & 1.4 \\
3-EC8 & 0.3 & 0.5 & 0.7 & 1.0 & 0.8 & 0.4 & 0.2 \\
Total MBs & 19.4 & 23.0 & 27.7 & 31.5 & 28.2 & 21.8 & 15.9 \\
2,3-DMC8 & 2.6 & 3.1 & 3.7 & 4.5 & 3.8 & 2.9 & 2.2 \\
2,4-DMC8 & 3.3 & 4.0 & 4.9 & 6.6 & 5.1 & 3.5 & 2.8 \\
2,5-DMC8 & 2.1 & 2.7 & 3.1 & 4.1 & 3.2 & 2.4 & 1.7 \\
2,6-DMC8 & 0.6 & 0.8 & 1.2 & 1.4 & 1.1 & 0.8 & 0.4 \\
Total DMs & 8.6 & 10.6 & 12.9 & 16.6 & 13.2 & 9.6 & 7.1 \\
Cracked products & 4.4 & 5.1 & 6.0 & 6.6 & 7.1 & 7.5 & 8.0 \\
Conversion (wt\%) & 32.4 & 38.7 & 46.6 & 54.7 & 48.5 & 38.9 & 31.0 \\
Isomerization selec- & 86.4 & 86.8 & 87.1 & 87.9 & 85.4 & 80.7 & 74.2 \\
tivity (\%) & & & & & & & \\
MBs/DBs & 2.3 & 2.2 & 2.1 & 1.9 & 2.1 & 2.3 & 2.2 \\
I/C & 6.4 & 6.6 & 6.8 & 7.3 & 5.8 & 4.2 & 2.9 \\
3-MC9/2,4-DMC8 & 2.5 & 2.4 & 2.3 & 1.9 & 2.3 & 2.6 & 2.8 \\
\hline LHSV 2 h-1 weight & catalyst & & & & \\
\hline
\end{tabular}

$\mathrm{LHSV}=2 \mathrm{~h}^{-1}$; weight of catalyst $=1 \mathrm{~g}$; flow of $\mathrm{H}_{2}=20 \mathrm{~mL} \mathrm{~min}^{-1} \mathrm{~g}^{-1}$; time on stream $=1 \mathrm{~h}$; MBs = monobranched isomers; $\mathrm{DBs}=$ dibranched isomers; pressure $=1 \mathrm{~atm}$.

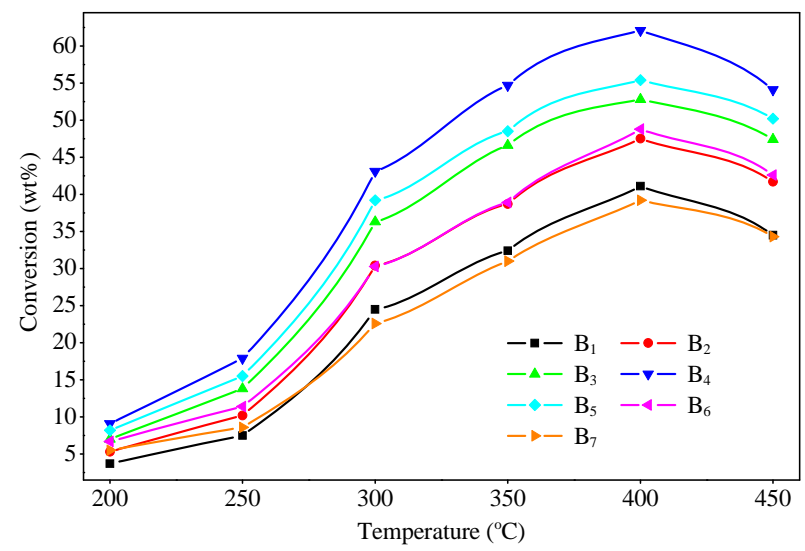

Fig. 6. Effect of temperature on $n$-decane conversion over B series catalysts.

ture increases, $n$-decane is more likely to be converted into cracked products rather than the corresponding isomerized products. Y zeolite has a three-dimensional channel structure with an aperture size of 7.4 $\AA$. Thus, the structure of Y zeolite does not thermodynamically favor the formation of dibranched $\mathrm{C}_{10}$ such as 2,3-DMC8 and 2,5-DMC8 at $200{ }^{\circ} \mathrm{C}$ or 3EC8 and 2,6-DMC8 even at $300{ }^{\circ} \mathrm{C}$. The formation of dibranched isomers from $n$-octane via monobranched isomers may involve the PCP intermediate as suggested by Zhang et al. [47]. The isomerization selectivity with increasing temperatures reached maximum at $350{ }^{\circ} \mathrm{C}$, which is a typical behavior of the occurrence of consecutive reactions. The rate of hydrocracking, as a secondary reaction, increased rapidly at temperatures above $350{ }^{\circ} \mathrm{C}$ over all the prepared catalysts. Specifically, catalyst $\mathrm{B}_{1}$ displayed a $3.7 \mathrm{wt} \% n$-decane conversion and a $54.1 \%$ isomerization selectivity at $200{ }^{\circ} \mathrm{C}$. Upon increasing the temperature to $250,300,350$, and $400{ }^{\circ} \mathrm{C}$, the $n$-decane conversion increased to $7.5,24.5,32.4$, and $41.1 \mathrm{wt} \%$, with corresponding isomerization selectivities of $72 \%, 84.1 \%, 86.4 \%$, and $85.2 \%$, respectively. However, further increases in the reaction temperature from 400 to $450{ }^{\circ} \mathrm{C}$ led to a reduced conversion from 41.1 to 34.5 wt $\%$, with a corresponding reduced isomerization selectivity from $85.2 \%$ to $78.3 \%$. The steady increase in conversion with

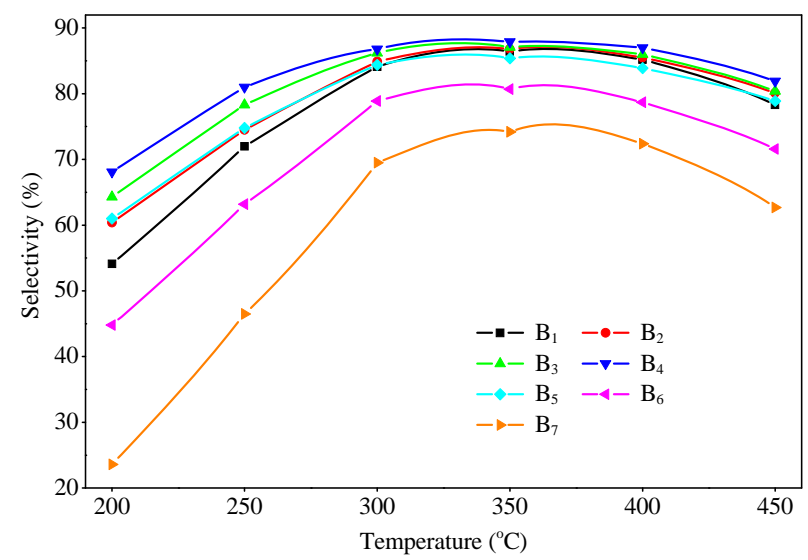

Fig. 7. Effect of temperature on the isomerization selectivity of $n$-decane over B series catalysts. 
increasing temperatures $\left(200-400^{\circ} \mathrm{C}\right)$ may be due to activation of the acid sites with temperature and the increase in isomerization selectivity may be attributed to the bifunctional character of the acid sites in the presence of the Pd nanoparticles. The introduction of $0.1 \mathrm{wt} \% \mathrm{Ni}$ into the catalyst $\mathrm{B}_{1}$ increased the $n$-decane conversion and isomerization selectivity at all studied temperatures. Over catalyst $B_{2}, n$-decane conversions of 5.3 , $10.2,30.4,38.7$, and $47.5 \mathrm{wt} \%$ were obtained at 200, 250, 300, 350 , and $400{ }^{\circ} \mathrm{C}$, respectively. The conversion values were considerably higher than those obtained over catalyst $\mathrm{B}_{1}$ at the respective temperatures. This result may be due to the activation of acid sites as explained earlier, rather than the introduction of more Ni species. Furthermore, the nanoparticle activity of the bimetallic combination $\mathrm{Ni}$ and Pd (both fcc-forming solid solution) may also contribute to the improved conversion values obtained. In contrast, only a small increase in the isomerization selectivity was observed as the catalyst was switched from $\mathrm{B}_{1}$ to $\mathrm{B}_{2}$, i.e., $54.1 \%, 72 \%, 84.1 \%, 86.4 \%$, and $85.2 \%$ to $60.4 \%, 74.5 \%, 84.9 \%, 86.8 \%$, and $85.5 \%$ at $200,250,300,350$, and $400{ }^{\circ} \mathrm{C}$, respectively. The small increase in the isomerization values may be attributed to the nanoparticle character of $\mathrm{Ni}$-Pd. However, the selectivity decreased considerably at temperatures above $350{ }^{\circ} \mathrm{C}$ over all the catalysts when the metal combination exceeds threshold values. Thus, the decrease in selectivity may be due to either the large particles formed as a result of Ni-Pd combination, which affect the acidity of the support, or the presence of Ni oxide particles that are not completely reduced, hence affecting the acidity on the surface of the support. Among all the catalysts, $\mathrm{B}_{4}(0.3 \mathrm{wt} \% \mathrm{Ni}$ loaded over 0.1 wt $\%$ Pd catalyst) showed high conversion as well as high isomerization selectivity at all temperatures studied. Similar observations were made by Jao et al. [36] in Ni-Pt/MOR and Jordao et al. [48] in Ni-Pt/HUSY that were examined in the isomerization of $n$-hexane. Similar trends, i.e., increases in $n$-decane conversion as well as cracking activity and small increases in isomerization selectivity with increasing reaction temperatures, were observed over all the remaining Pd-, $\mathrm{Ni}-\mathrm{Pd}-$, and Ni-loaded catalytic systems, thus indicating the bifunctional nature of the catalysts.

\subsubsection{Effect of Ni addition on n-decane conversion and isomerization selectivity}

The effect of $\mathrm{Ni}$ addition on $n$-decane conversion was studied by comparing the $n$-decane conversion over the $\mathrm{Ni}$-containing and $\mathrm{Ni}$ free catalysts at a given reaction temperature. The addition of $0.1 \mathrm{wt} \% \mathrm{Ni}$ over $0.1 \mathrm{wt} \% \mathrm{Pd} / \mathrm{HY}$ enhanced the $n$-decane conversion from 3.7 to $5.3 \mathrm{wt} \%$ at $200{ }^{\circ} \mathrm{C}$. At $400{ }^{\circ} \mathrm{C}$, the conversion increased to $41.1-47.5 \mathrm{wt} \%$. Similar increasing trends were observed up to a Ni added amount of $0.3 \mathrm{wt} \%$ (over $0.1 \mathrm{wt} \% \mathrm{Pd}$ ) in the HY series catalysts. Further increases in the $\mathrm{Ni}$ content (catalysts $\mathrm{B}_{5}$ and $\mathrm{B}_{6}$ ) led to a decreasing trend in $n$-decane conversion at all the temperatures studied. A maximum conversion of 62.1 wt $\%$ was obtained over catalyst $\mathrm{B}_{4}$ at $400{ }^{\circ} \mathrm{C}$. Also, Ni addition up to $0.3 \mathrm{wt} \%$ enhanced the isomerization selectivity. Catalyst $\mathrm{B}_{4}$ displayed the highest isomerization selectivity of $87.9 \%$ at $350{ }^{\circ} \mathrm{C}$, which was considerably higher than that observed over catalyst $\mathrm{B}_{1}$
(86.4\%). Further increases in the Ni content in the HY series catalysts (catalyst $\mathrm{B}_{5}$ ) led to a significant decrease in isomerization selectivity. The selectivity toward cracking could be controlled at all temperatures studied at $\mathrm{Ni}$ added amounts below 0.3 wt $\%$. The increase in $n$-decane conversion, isomerization selectivity, and cracking with increasing $\mathrm{Ni}$ added amounts was consistent with the results obtained by Rezgui et al. [26]. In a catalyst with higher metallic site-to-acid site $\left(N_{\mathrm{M}} / N_{\mathrm{A}}\right)$ ratios, the diffusion distance between two metallic sites may be shorter when compared with a catalyst with lower $N_{\mathrm{M}} / N_{\mathrm{A}}$ ratios. In the present study, the initial increase in conversion, with a low extent of cracking, observed upon increasing $\mathrm{Ni}$ added amounts may be attributed to the formation and growth of catalytically active Ni-Pd bimetallic particles at the nanometer scale as well as an improved balance between the acid sites of the support and bimetallic particles. The high activity and selectivity observed for catalyst $\mathrm{B}_{4}$ may be attributed to the improved metal-acid sites balance. As discussed above, the TEM studies showed that the average particle size of the bimetallic particles increased with increasing $\mathrm{Ni}$ loading. According to the TEM analysis, catalyst $\mathrm{B}_{4}$ featured an average particle size of 6.08 $\mathrm{nm}$. Furthermore, the XPS spectrum of catalyst $\mathrm{B}_{4}$ revealed that the Pd and Ni oxides were completely reduced to their respective metallic states. The added Ni species may increase the total number of active metallic sites, i.e., the metallic sites/acid sites ratio may increase to an optimum value toward favoring isomerization reactions. The initial increase in hydroisomerization selectivity and cracking with increasing $\mathrm{Ni}$ added contents was attributed to the availability of more metallic sites in the vicinity of the acid sites, thus enabling rapid hydrogenation of the carbenium ions and subsequent desorption as alkanes before the latter underwent cracking reactions. Thus, the probability of cracking the olefinic intermediate during migration from one metallic site to another site was reduced [49]. The decreasing trend in conversion with increasing cracking observed over catalysts with higher Ni contents may be due to the formation of larger bimetallic particles and the presence of unreduced $\mathrm{Ni}$ as $\mathrm{NiO}$ and $\mathrm{NiAl}_{2} \mathrm{O}_{4}$, as evidenced by XPS. Catalyst $\mathrm{B}_{6}$ featured an average particle size of $9.07 \mathrm{~nm}$ based on TEM analysis. Similar results were reported by Kuznets et al. [50] in the isomerization of $n$-octane over Pt/HY catalysts, wherein the cracking rate decreased with increasing Pt contents to up to $0.6 \mathrm{wt} \%$ and then became independent of Pt loading. Such large bimetallic particles may block the pores of the zeolite and restrict the movement of bulky reaction intermediates. Additionally, the presence of unreduced Ni species, which are inactive in the hydrogenation-dehydrogenation step, may affect the strength of the acid sites, leading to lower activity. Also, the decrease in crystallinity of the supports, as indicated by XRD, likely contributed to the lower activity. The Ni-loaded catalyst $\left(\mathrm{B}_{7}\right)$ displayed a considerably lower $n$-decane conversion, with a higher cracking tendency, when compared with catalyst $\mathrm{B}_{4}$.

\subsubsection{Effect of temperature on the selectivity of individual n-decane isomers}

The effect of temperature on the selectivity of individual $n$-decane isomers was examined over $\mathrm{B}_{4}$, and the results are 


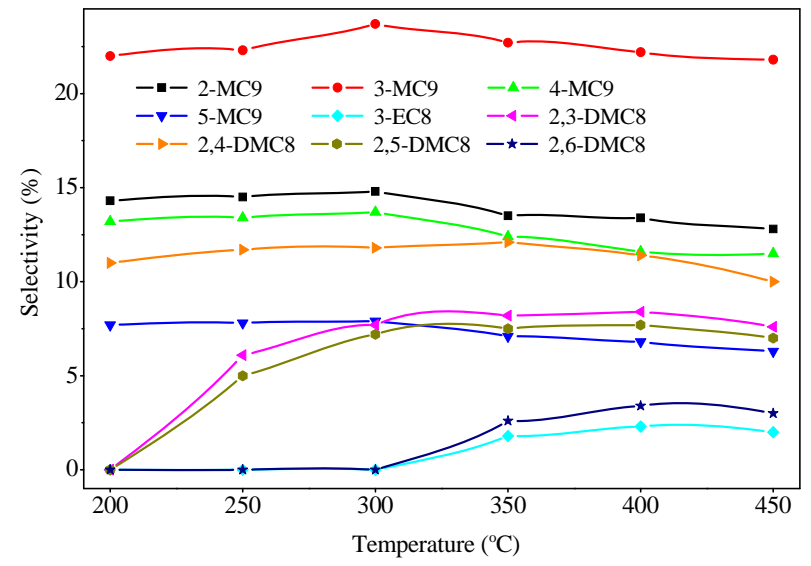

Fig. 8. Effect of temperature on the selectivity of individual $n$-decane isomers over $\mathrm{B}_{4}$ catalyst.

illustrated in Fig. 8. The selectivity of the monobranched isomers 2-MC9, 3-MC9, 4-MC9, 5-MC9, and 3-EC8 increased with increasing temperatures to up to $300{ }^{\circ} \mathrm{C}$ and thereafter decreased over all the catalysts studied. The selectivity of 2-MC9 decreased more than that of 3-MC9. Thus, 3-MC9 formed more readily than 2-MC9. This result was consistent with that observed by Steijns et al. [51] in the hydroisomerization of $n$-dodecane. Additionally, this was a general observation in the hydroisomerization of $n$-alkanes (especially those with $\geq 9$ carbon atoms). This result is best explained by the occurrence of a PCP mechanism involved in the isomerization reaction [52]. The formation of 3-EC8 over the catalysts, even at very low conversions, could not be explained by the occurrence of a protonated cyclopropane mechanism. The primary formation of 3-EC8 can most likely be explained by the participation of a B isomerization reaction of protonated cyclobutane intermediates (PCB) as proposed by Martens et al. [53]. The selectivity of the dibranched isomers 2,3-DMC8, 2,4-DMC8, 2,5-DMC8, and 2,6-DMC8 increased with increasing temperatures. Among these dibranched isomers, 2,4-DMC8 featured the highest selectivity. The present data indicate that the predominate dibranched isomers were those featuring distant methyl groups (2,3-DMC8 and 2,4-DMC8). Similarly to the first branching, the formation of less bulky PCP intermediates involved in the second branching is strongly favored, thus explaining the low selectivities for dibranched isomers containing methyl groups within close proximities to each other [54]. According to Lucas et al. [55], the formation of the dibranched decane isomer can be attributed to the formation of a bulkier transition state and intermediates of isomers, such as 2,2-dimethyloctane and 3,3-dimethyloctane, with two branches on the same carbon of the main chain. Their formation is favored in zeolites without steric hindrance for the diffusion of products. It should be noted that for zeolites with relatively large pores, such as beta zeolites, the presence of these isomers is more predominant. The increase in the extent of formation of dibranched isomers with increasing temperatures, as well as conversion, indicates that the dibranched isomers are secondary products formed from primary monobranched isomers by formation of a proto- nated cyclopropane intermediate. Similar results have been reported in our previous studies [33-35]. In contrast, tribranched isomers were not detected regardless of the catalyst investigated in this work. This result was attributed to the relatively high temperatures employed, which do not favor the thermodynamic formation of tribranched isomers. Moreover, fast cracking of the latter hydrocarbons was responsible for the absence of tribranched isomers in the final products [47]. The selectivity of the monobranched isomers was higher than that of the dibranched isomers. The earlier observations indicated that the pore structure, size, and kinetic diameter of the reactants, products, and intermediates contributed to the different selectivities of the dibranched isomers. Zeolite $Y$ has a faujasite structure with a three-dimensional channel system of $12 \mathrm{MR}$ (pore size: $7.4 \AA$ ) intersections [56]. The kinetic diameters of $n$-decane, monobranched, and dibranched isomers increased in the order of $n$-decane < monobranched isomers < dibranched isomers. Hence, the formation of the dibranched isomers may be sterically hindered by the presence of metallic particles in the pores.

\subsubsection{Effect of temperature on the $M B_{S} / D B_{S}$ ratio}

The effect of temperature on the ratios of the octane isomers over the catalysts is illustrated in Fig. 9. The ratio of 3-MC9/2,4-DMC8 decreased with increasing reaction temperatures to up to $400{ }^{\circ} \mathrm{C}$. It is generally considered that the branching of olefins occurs through the protonated cyclopropane intermediate as per the comprehensive description of carbenium ion rearrangement and cleavage by Weitkamp [52]. From the point of view of PCP mechanism, the isomerization of monobranched to dibranched decanes proceeds through secondary and tertiary carbocations, and therefore it should be thermodynamically favorable. The 3-MC9/2,4-DMC8 ratio decreased with increasing temperatures and Ni contents up to the threshold value. The increase in the extent of dibranched decane formation with increasing Ni contents as well as temperatures indicates that the addition of $\mathrm{Ni}$ and higher reaction temperatures favors the protonated cyclopropane intermediate mechanism, which is considered to be slower than the 1,2-alkyl hydride shift mechanism, which leads to the formation of

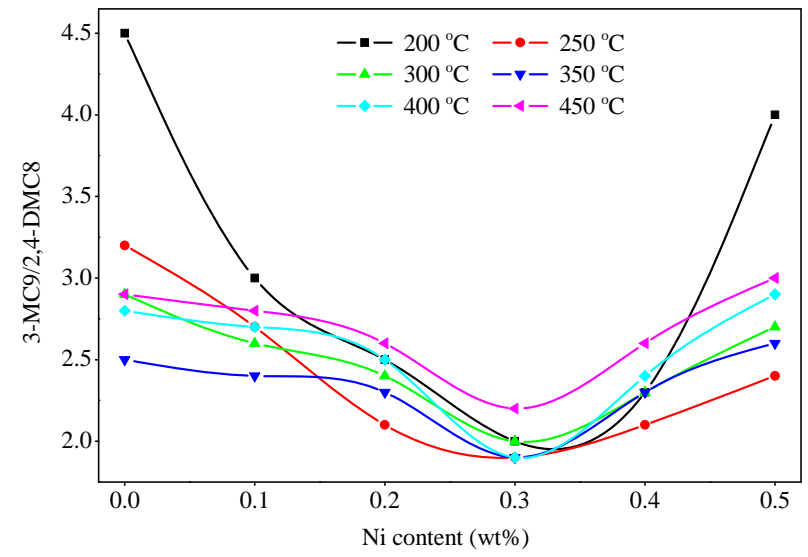

Fig. 9. Effect of $\mathrm{Ni}$ addition on the 3-MC9/2,4-DMC8 ratio over B series catalysts at different temperatures. 
monobranched isomers. The increased extent in the occurrence of the PCP mechanism can be attributed to a better balance between the formed metal particles and the acid sites. Catalysts featuring large metal particles do not favor the PCP mechanism as the large particle size affects the development of optimum metal-acid site balance. The unreduced $\mathrm{Ni}$ (as observed in the XPS analysis), although not active in the dehydrogenation-hydrogenation step, may play a role in the isomerization of $n$-decane as well as the ratio of the isomers formed. The decrease in the 3-MC9/2,4-DMC8 ratio with increasing Ni contents indicates that $\mathrm{Ni}$ addition facilitates the formation of the dibranched isomers through a PCP intermediate mechanism and suppresses the 1,2-alkyl hydride shift reaction, which typically leads to the formation of 3-MC9 from 2-MC9. Hence, the $n$-decane isomerization is considered to proceed via a carbenium ion rearrangement and cleavage mechanism. According to the comprehensive description of rules for carbenium ion rearrangement and cleavage given by Brouwer [57], carbenium ion isomerizations, which lead to a change in the degree of branching, proceed through a protonated cyclopropane PCP ring intermediate formation mechanism.

\subsubsection{Effect of Ni addition on isomerization/cracking (I/C) ratio}

The I/C ratio of a catalyst is an indication of its suitability for isomerization reactions. Excellent isomerization catalysts have very high I/C ratios. As observed in Fig. 10, the I/C ratio increased with increasing $\mathrm{Ni}$ added contents to up to $0.3 \mathrm{wt} \%$ (B catalyst). Further increases in the Ni content lowered the I/C ratio, indicating the higher cracking activity of larger bimetallic particles. Overall, the catalytic system I/C ratio decreased with increasing temperatures, indicating that higher temperatures favor cracking.

\subsubsection{Effect of reaction time}

The performance of the catalyst was further examined over a reaction period of $15 \mathrm{~h}$ at $400{ }^{\circ} \mathrm{C}$. The results are shown in Fig. 11. All catalysts showed large decreases in the conversion with increasing reaction times up to $5 \mathrm{~h}$, after which small de-

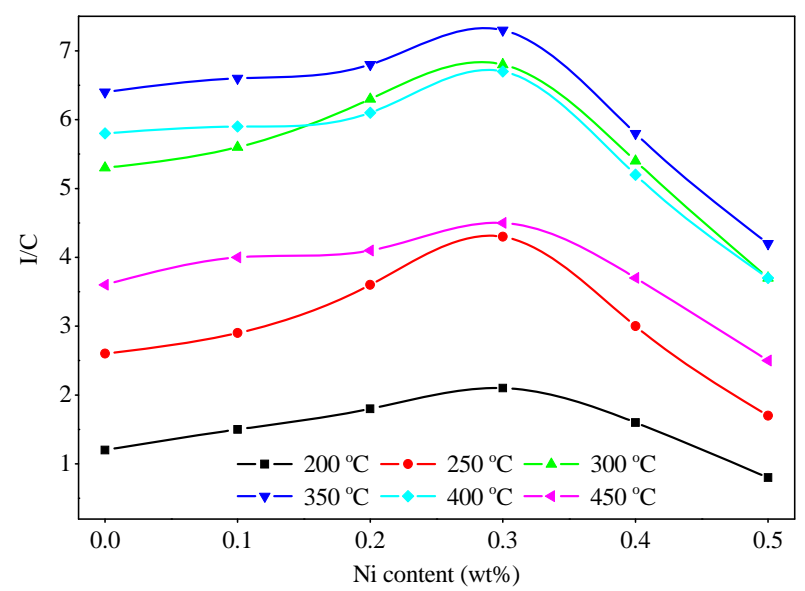

Fig. 10. Effect of $\mathrm{Ni}$ addition on the $\mathrm{I} / \mathrm{C}$ ratio over $\mathrm{B}$ series catalysts at different temperatures.

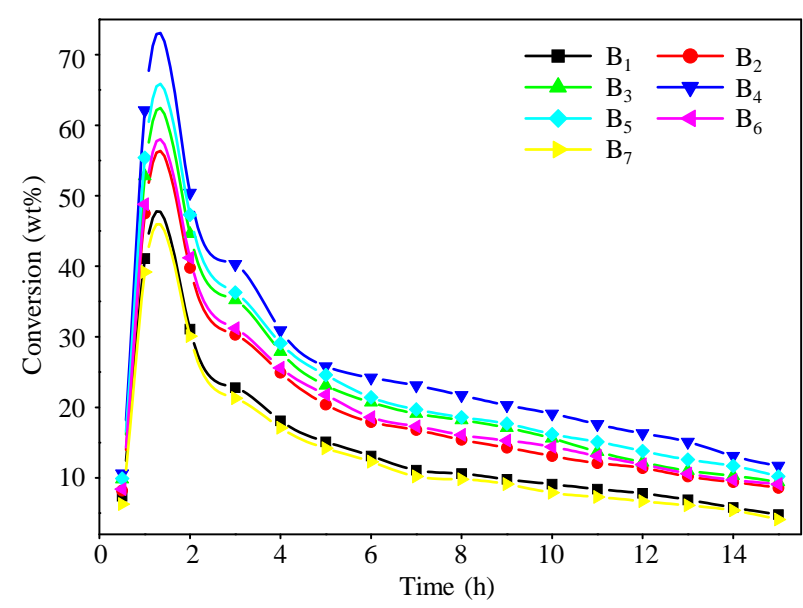

Fig. 11. Time-on-stream behavior of $n$-decane hydroisomerization over B series catalysts.

creases were observed with increasing reaction times up to 15 h. Among all catalysts, $\mathrm{B}_{4}$ displayed the lowest reduction. In contrast, $\mathrm{B}_{1}$ and $\mathrm{B}_{7}$ showed the highest reduction in activity. The higher (sustained) performance of $\mathrm{B}_{4}$ can be explained in terms of the formation of catalytically active bimetallic particles and better balance between the metal and acid sites. The decrease in activity of the catalysts can be related to the formation of coke, which can block the active sites of the catalysts.

To understand the role of the noble metal Pd in HY zeolite on the performance of the catalysts, the reaction was conducted under optimized conditions (LHSV $=2 \mathrm{~h}^{-1}$; weight of catalyst $=1 \mathrm{~g} ; \mathrm{H}_{2}$ flow $=20 \mathrm{~mL} \mathrm{~min}^{-1} \mathrm{~g}^{-1}$; reaction time $=1 \mathrm{~h}$; pressure = $1 \mathrm{~atm}$; reaction temperature $=350^{\circ} \mathrm{C}$ ) using $\mathrm{HY}$ zeolite (without metal loading) as a catalyst. HY achieved a conversion of $12.8 \mathrm{wt} \%$ and an isomerization selectivity of 38.4\% and generated a high amount of cracked products $(21.1 \%)$. In contrast, $\mathrm{B}_{4}$ catalyst, when operating under optimized conditions, achieved a conversion of $54.7 \mathrm{wt} \%$, with a corresponding isomerization selectivity of $87.9 \%$ and a low amount of cracked products (6.6\%). These performance values were considerably better than those achieved by HY zeolite. Based on these results, it can be concluded that the presence of noble metal catalysts plays a vital role in achieving high conversion and product selectivity.

To examine the recyclability of the catalysts, the reaction was performed for five successive cycles under the aforementioned optimized conditions over $\mathrm{B}_{4}$. After each cycle, the catalyst was regenerated at $500{ }^{\circ} \mathrm{C}$ in air. In general, both the conversion and selectivity decreased after each cycle; however, the reduction was not significant (Table 3).

Table 3

Recyclability of the $\mathrm{B}_{4}$ catalyst.

\begin{tabular}{lcc}
\hline No. of cycles & Conversion (wt\%) & Selectivity (\%) \\
\hline Fresh catalyst & 54.7 & 87.9 \\
1st cycle & 54.4 & 87.5 \\
2nd cycle & 54.1 & 87.2 \\
3rd cycle & 53.8 & 86.9 \\
4th cycle & 53.6 & 86.6 \\
5th cycle & 53.4 & 86.4 \\
\hline
\end{tabular}




\section{Conclusions}

Y zeolite was loaded with $\mathrm{Pd}$ and $\mathrm{Ni}$ at varying amounts using an impregnation method. The resulting products were characterized and examined as catalysts in the hydroisomerization of $n$-decane. The XRD results confirmed the good crystallinity of the commercial Y zeolite support. Upon loading with $\mathrm{Ni}$ at increasing amounts, the structure and crystallinity of the resulting metal-loaded zeolites decreased. The TEM analysis revealed the formation of bimetallic (Ni-Pd) nanoparticles. The ESCA study revealed complete reduction of $\mathrm{Ni}$ up to a Ni loading of $0.3 \mathrm{wt} \%$ over $0.1 \mathrm{wt} \%$ Pd-loaded HY. The TPR results showed a decrease in the Pd reduction temperature with increasing $\mathrm{Ni}$ added amounts. The acidity measurements by TPDA indicated that some of the acid sites were occupied by the Ni species. Owing to the excellent metal-acid site balance between the bimetallic particles and acid sites of the support, catalyst $\mathrm{B}_{4}$ showed higher activity, dibranched isomer selectivity, and performance sustainability in the hydroisomerization of $n$-decane when compared with the remaining catalysts.

\section{Acknowledgments}

The authors are gratefully acknowledged for the catalyst characterization and product analysis support from Chennai Petroleum Corporation Limited (CPCL), Chennai, India.

\section{References}

[1] I. E. Maxwell, Catal. Today, 1987, 1, 385-413.

[2] S. V. Konnov, Y. V. Monakhova, E. E. Knyazeva, V. V. Yushchenko, O. A. Ponomareva, I. I. Ivanova, Pet. Chem., 2009, 49, 79-85.

[3] Z. Paal, in: G. J. Antos, A. M. Aitani, J. M. Parera, eds., Catalytic Naphtha Reforming: Science and Technology, Marcel Dekker, New York, 1995, 19-44.

[4] G. C. Bond, Heterogeneous Catalysis: Principles and Applications, Oxford Science Publications, Oxford, 1986

[5] Z. Paal, in: Z. Paal, P. G. Menon, eds., Hydrogen Effects in Catalysis: Fundamentals and Practical Applications, Dekker, New York, 1988, 449-497.

[6] K. B. Chi, Z. Zhao, Z. J. Tian, S. Hu, L. J. Yan, T. S. Li, B. C. Wang, X. B.
Meng, S. P. Gao, M. W. Tan, Y. F. Liu, Petrol. Sci., 2013, 10, 242-250.

[7] F. Bauer, K. Ficht, M. Bertmer, W. D. Einicke, T. Kuchling, R. Gläser, Catal. Sci. Technol., 2014, 4, 4045-4054.

[8] I. E. Maxwell, W. H. J. Stork, Stud. Surf. Sci. Catal., 1991, 58, 571-630.

[9] S. W. Lee, S. K. Ihm, Ind. Eng. Chem. Res., 2013, 52, 15359-15365.

[10] Y. Yao, Y. J. Tian, H. H. Wu, S. X. Lu, Fuel Processing Technol., 2015, 133, 146-151.

[11] J. Zhao, G. G. Wang, L. H. Qin, H. Y. Li, Y. Chen, B. J. Liu, Catal. Commun., 2016, 73, 98-102.

[12] V. Hopkins, D. R. Wilson, Ind. Eng. Chem. Prod. Res. Dev., 1964, 3, 38-43.

[13] P. B. Weisz, Adv. Catal., 1962, 13, 137-190.

[14] N. Kasian, E. Verheyen, G. Vanbutsele, K. Houthoofd, T. I. Koranyi, J. A. Martens, C. E. A. Kirschhock, Microporous Mesoporous Mater., 2013, 166, 153-160.

[15] J. A. Martens, P. A. Jacobs, J. Weitkamp, Appl. Catal., 1986, 20, 239-281.

[16] J. A. Martens, P. A. Jacobs, J. Weitkamp, Appl. Catal., 1986, 20, 283-303.

[17] J. A. Martens, M. Tielen, P. A. Jacobs, Catal. Today, 1987, 1, 435-453.

[18] M. Guisnet, Catal. Today, 2013, 218, 123-134.

[19] A. S. Arifulin, A. B. Vol-Epshtein, A. A. Krichko, M. K. Yulin, Khimiya Tverdogo Topliva (Moscow, Russian Federation), 1976, (5), 122126.

[20] J. A. Martens, J. Perez-Pariente, P. A. Jacobs, NATO ASI Series C Math. Phys. Sci., 1986, 165, 115-129.

[21] J. A. Martens, D. Verboekend, K. Thomas, G. Vanbutsele, J. P. Gilson, J. Pérez-Ramírez, ChemSusChem, 2013, 6, 421-425.

[22] J. A. Martens, D. Verboekend, K. Thomas, G. Vanbutsele, J. Pérez-Ramírez, J. P. Gilson, Catal. Today, 2013, 218, 135-142.

[23] F. Alvarez, F. R. Ribeiro, G. Perot, C. Thomazeau, M. Guisnet, J. Catal., 1996, 162, 179-189.

[24] G. D. Zakumbaeva, B. B. Tuktin, M. Z. Parmankulov, R. I. Egizbaeva, Eurasian Chem.-Technol. J., 2001, 3, 91-96.

[25] S. P. Elangovan, C. Bischof, M. Hartmann, Catal. Lett., 2002, 80, $35-40$.

[26] Y. Rezgui, M. Guemini, Appl. Catal., 2005, 282, 45-53.

[27] F. Dorado, R. Romero, P. Canizares, Appl. Catal. A, 2002, 236, 235-243.

[28] P. Canizares, A. De Lucas, J. L. Valverde, F. Dorado, Ind. Eng. Chem. Res., 1997, 36, 4797-4808.

[29] M. M. J. Treacy, J. B. Higgins, Collection of Simulated XRD Powder Patterns for Zeolites, 4th ed., Elsevier, Amsterdam, 2001.

[30] G. Faherazzi, A. Benedetti, A. Martorans, S. Giuliano, D. Duca, G. De-

\section{Graphical Abstract}

Chin. J. Catal., 2016, 37: 1907-1917 doi: 10.1016/S1872-2067(16)62507-X

\section{Effect of metal content on the activity and product selectivity of n-decane hydroisomerization over Ni-Pd/HY zeolite}

Dhanapalan Karthikeyan *, Raji Atchudan *, Raji Sivakumar Arignar Anna College of Arts and Science, India;

Yeungnam University, Korea;

Anna University, India

Zeolite-Y was impregnated with $0.1 \mathrm{wt} \% \mathrm{Pd}$ and 0.1 to $0.5 \mathrm{wt} \% \mathrm{Ni}$. The synthesized catalyst shows an enhanced activity, dibranched isomers selectivity and sustainability of the catalysts in $n$-decane hydroisomerization.

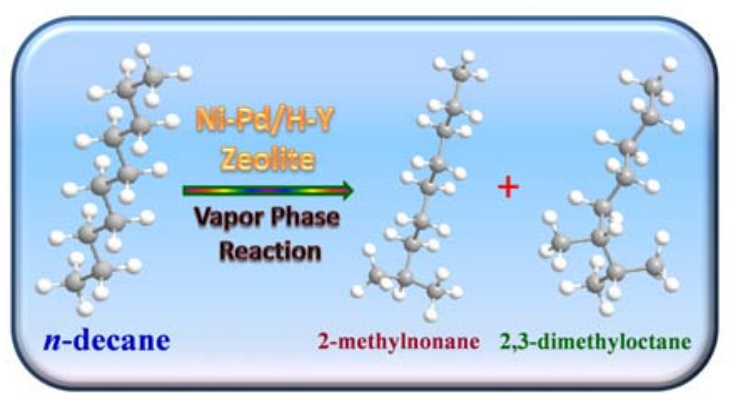


ganello, Catal. Lett., 1990, 6, 263-269.

[31] B. D. Cullity, Elements of X-Ray Diffraction, 2nd ed., Addison-Wesley, New York, 1978.

[32] L. J. Leu, L. Y. Hou, B. C. Kang, C. Li, S. T. Wu, J. C. Wu, Appl. Catal. A, 1991, 69, 49-63.

[33] D. Karthikeyan, N. Lingappan, B. Sivasankar, N. John Jabarathinam, Appl. Catal. A, 2008, 345, 18-27.

[34] D. Karthikeyan, N. Lingappan, B. Sivasankar, Korean J. Chem. Eng., 2008, 25, 987-997.

[35] D. Karthikeyan, N. Lingappan, B. Sivasankar, N. J. Jabarathinam, Ind. Eng. Chem. Res., 2008, 47, 6538-6546.

[36] R. M. Jao, T. B. Lin, J. R. Chang, J. Catal., 1996, 161, 222-229.

[37] A. De Lucas, P. Sanchez, A. Funez, M. J. Ramos, J. L. Valverde, Ind. Eng. Chem. Res., 2006, 45, 8852-8859.

[38] P. Canizares, A. De Lucas, F. Dorado, A. Duran, I. Asencio, Appl. Catal. A, 1998, 169, 137-150.

[39] M. Suzuki, K. Tsutsumi, H. Takahashi, Y. Saito, Zeolites, 1989, 9, 98-103.

[40] J. S. Feeley, W. M. H. Sachlter, Zeolites, 1990, 10, 738-745.

[41] M. Suzuki, K. Tsutsumi, H. Takahashi, Zeolites, 1982, 2, 51-58.

[42] M. Narayana, J. Michalik, S. Contarini, L. Kevan, J. Phys. Chem., 1985, 89, 3895-3899.

[43] Ch. Minchev, V. Knazirev, L. Kosova, V. Pechev, W. Grunsser, F. Schimidt, in: L. V. C. Rees., eds., Proc. Fifth Int. Conf. on Zeolites, London, 1980, 335-340.

[44] S. Narayanan, Zeolites, 1984, 4, 231-234.
[45] S. Y. Xiao, Z. Y. Meng, J. Chem. Soc. Faraday Trans., 1994, 90, 2591-2595.

[46] M. D. Romero, A. De Lucas, J. A. Calles, A. Rodriguez, Appl. Catal., 1996, 146, 425-441.

[47] W. Zhang, P. G. Smirniotis, J. Catal., 1999, 182, 400-416.

[48] M. H. Jordao, V. Simoes, A. Montes, E. Cardoso, Stud. Surf. Sci. Catal., 2000, 130, 2387-2392.

[49] G. E. Giannetto, G. R. Perot, M. R. Guisnet, Ind. Eng. Chem. Prod. Res. Dev., 1986, 25, 481-490.

[50] P. N. Kuznetsov, J. Catal., 2003, 218, 12-23.

[51] M. Steijns, G. Froment, P. Jacobs, J. Uytterhoeven, J. Weitkamp, Ind. Eng. Chem. Prod. Res. Dev., 1981, 20, 654-660.

[52] J. Weitkamp, Ind. Eng. Chem. Prod. Res. Dev., 1982, 21, 550-558.

[53] J. A. Martens, P. A. Jacobs, in: J. B. Moffat, eds., Theoretical Aspects of Heterogeneous Catalysis, Van Nostrand Reinhold, New York, 1990, $52-109$.

[54] P. Meriaudeau, V. A. Tuan, F. Lelebvre, V. T. Nghiem, C. Naccache, Microporous Mesoporous Mater., 1998, 22, 435-449.

[55] A. De Lucas, J. L. Valverde, P. Sanchez, F. Dorado, M. J. Ramos, Appl. Catal. A, 2005, 282, 15-24.

[56] C. Baerlocher, W. H. Meier, D. H. Olson, Atlas of Zeolite Framework Types, 5th ed., Elsevier, Amsterdam, 2001.

[57] D. M. Brouwer, in: R. Prins, G. C. A. Schuit eds., Chemistry and Chemical Engineering of Catalytic Processes, Sijthoff and Noordhoff, Germantown, MD, 1980, 137-160.

\title{
金属含量对Ni-Pd/H-Y上正癸烷加氢异构化反应活性和产物选择性的影响
}

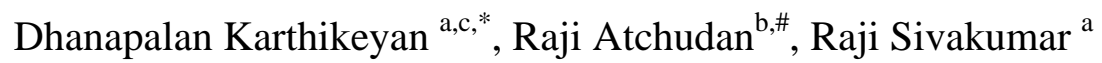 \\ ${ }^{a}$ Arignar Anna艺术与科学学院化学系, 克里希纳吉里635001, 泰米尔纳德邦, 印度 \\ b岭南大学化学工程学院, 庆山38541, 韩国 \\ c安那大学化学系(库因地校区), 金奈600025, 印度
}

摘要: 在Y分子篮上浸渍 $0.1 \mathrm{wt} \% \mathrm{Pd}$ 和 $0.1-0.5 \mathrm{wt} \% \mathrm{Ni}$, 用X射线衍射表征了该催化剂的结晶度, 用透射电镜测得平均金属粒 径. 催化剂中Pd和 $\mathrm{Ni}$ 的化学态用 $\mathrm{X}$ 射线光电子能谱测定, 其酸性则用氨-程序升温脱附进行了表征, 发现一些酸位被 $\mathrm{Ni}^{2+}$ 离 子交换. 采用程序升温还原表征了 HY 分子篮负载的Pd, Ni和Pd-Ni催化剂的还原性能. 正癸烷加氢异构化反应在200-450 ${ }^{\circ} \mathrm{C}$ 和 $1 \mathrm{~atm}$ 条件下进行. 结果发现, 当 $0.1 \mathrm{wt} \% \mathrm{Pd} / \mathrm{HY}$ 中 Ni添加量增至 $0.3 \mathrm{wt} \%$ 时, 正癸烷转化率和异构化选择性增加. 单支 链和双支链异构体选择性的增加表明该反应遵循质子化环丙烷中间体机理. Ni添加量超过阈值导致活性和异构化选择性 急剧下降. 综上可见, 双金属催化剂更有利于选择性生成双支链异构体, 其辛烷值更高.

关键词: 加氢异构化; 正癸烷; Y分子篮; 钯; 浸渍方法

收稿日期: 2016-05-18. 接受日期: 2016-07-09. 出版日期: 2016-11-05.

*通讯联系人. 电子信箱: dkarthikeyan05@yahoo.co.in

\#通讯联系人. 电子信箱: atchudanr@yu.ac.kr

本文的英文电子版由Elsevier出版社在ScienceDirect上出版(http://www.sciencedirect.com/science/journal/18722067). 